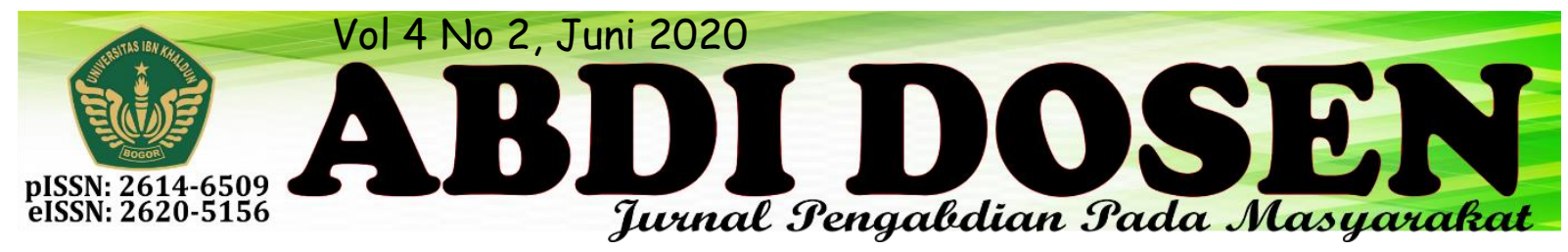

\title{
PEMBERDAYAAN MASYARAKAT DALAM BUDIDAYA, PENGELOLAAN DAN PEMANFAATAN LAHAN STRATEGIS SECARA PRODUKTIF
}

\author{
Sutisna $^{1}$, Freza Riana ${ }^{2}$, Dyah Ayu Nafisah ${ }^{3}$ \\ stn.sutisna@ gmail.com ${ }^{1}$ \\ freza@uika-bogor.ac.id ${ }^{2}$ \\ ica.dyah@gmail.com ${ }^{3}$
}

Fakultas Agama Islam ${ }^{1}$, Fakultas Teknik dan Sains ${ }^{2}$, Mahasiswa KKN Kelompok 11\&12 Tahun $2019^{3}$

\begin{abstract}
ABSTRAK
KKN merupakan proses pembelajaran mahasiswa melalui kegiatan langsung ditengah- tengah masyarakat, dan mahasiswa berupaya untuk menjadi bagian dari masyarakat secara aktif dan kreatif terlibat dalam dinamika yang terjadi di masyarakat. Kuliah Kerja Nyata (KKN) adalah salah satu wujud pengabdian mahasiswa kepada masyarakat lewat pemberian bantuan, pemberdayaan, pelatihan, penyuluhan, pendampingan, dan untuk menyadarkan potensi yang dimiliki, serta membantu meningkatkan kualitas hidup dan pembangunan. Mahasiswa akan mendapatkan kemampuan generatif berupa life keterampilan hidup. Desa Karehkel, Kecamatan Leuwiliang mempunyai luas wilayah 420 ha. Berdasarkan kondisinya, lahan yang ada terbagi dalam dua ekosistem, yaitu ekosistem lahan sawah dan kolam, serta ekosistem lahan darat/kering. Luas lahan sawah sejumlah 180 ha dan luas lahan kering, dan permukiman sejumlah 240 ha. Program kerja KKN yang akan dilaksanakan salah satunya adalah penanaman dan pembagian 6000 bibit pohon. Warga dituntut agar bisa membudidayakan pohon serta mengelolanya dan memanfaatkan lahan kosong yang dimilikinya. Kegiatan penanaman ini dimaksudkan untuk melestarikan lingkungan di Kecamatan Leuwiliang terutama di Desa Karehkel. Dari program ini Mahasiswa berperan sebagai fasilitator, dinamisator dan motivator. Pelaksanaan kegiatan KKN dimulai dari tanggal 06 Agustus 2019 - 06 Agustus 2019 ini relatif berjalan lancar. Dengan demikian, setelah kegiatan KKN ini berakhir diharapkan masyarakat Desa Karehkel dapat mengembangkan dan memanfaatkan sumberdaya di alam sekitarnya. Maka setiap kegiatan yang telah berlangsung secara kontinyu, tetap dipertahankan untuk membekali diri sebagai bekal dikemudian hari.
\end{abstract}

Kata kunci: KKN, Pemberdayaan, Penanaman.

\section{PENDAHULUAN}

\section{Latar Belakang}

Kuliah Kerja Nyata (KKN) merupakan salah satu mata kuliah intrakulikuler yang diselenggarakan oleh akademik diseluruh perguruan tinggi yang wajib diikuti oleh seluruhmahasiswa dengan bertujuan untuk meningkatkan

kemampuan dan wawasan mahasiswa sebagai bekal hidup dimasyarakat setelah lulus nanti. Pada dasarnya, kuliah kerja nyatta (KKN) merupakan suatu bentuk pengabdian nyata seorang mahasiswa kepada masyarakat dengan seutuhnya. Universitas Ibn Khaldun Bogor (UIKA) 
sebagai salah satu lembaga pendidikan yang berada dikawasan Kota Bogor memiliki kewajiban untuk berperan serta secara aktif dalam pembangunan dibidang pemberdayaan lingkungan, kesehatan, pendidikan serta ekonomi. Peran serta tersebut bukan hanya dilakukan oleh mahasiswa saja, namun juga masyarakat disekitar kampus atau masyarakat luas. Mahasiswa KKN juga mengadakan pertemuan secara rutin membahas program kerja. Ketika penerjunan ke lokasi KKN, para mahasiswa melakukan kegiatan observasi. Kegiatan ini dilakukan sebelum mahasiswa benar-benar terjun ke lokasi KKN. Kegiatan ini dilakukan untuk mengamati secara langsung terhadap situasi, kondisi, sarana, dan prasarana yang ada di lokasi KKN dalam hal ini guna mendukung proses kuliah kerja nyata di lokasi tersebut.

Desa Karehkel merupakan salah satu desa di wilayah Kecamatan Leuwiliang Kabupaten Bogor yang terbagi dalam 5 Dusun, 13 Rukun Warga (RW), dan 42 Rukun Tetangga (RT). Sasaran

\section{METODE}

Metode penelitian adalah cara utama yang digunakan dalam proses pengumpulan dan analisis data yang dilakukan secara sistematis dan logis untuk mencapai tujuan tertentu. Metode yang dilakukan dalam pelaksanaan rangkaian program KKN Tematik 2019 oleh kelompok 11 \& 12 yaitu dengan cara wawancara terhadap tokoh masyarakat dan pegawai kantor desa di Desa Karehkel. Wawancara adalah cara menghimpun bahan - bahan keterangan Yang dilaksanakan dengan tanya jawab secara lisan, sepihak, bertatap muka dan dengan arah tujuan yang telah ditentukan. Ada dua jenis wawancara yang dapat dilakukan dalam penelitian ini dilaksanakan di Kampung Bongas RT 1 \& 2 / RW 08 di Desa Karehkel dengan jumlah penduduk 12.773 jiwa yang terdiri dari 6.637 lakilaki dan 6.136 perempuan. Desa Karehkel, Kecamatan Leuwiliang mempunyai luas wilayah 420 ha. Luas lahan sawah sejumlah 180 ha dan luas lahan kering dan permukiman sejumlah 240 ha. Di Desa Karehkel khususnya wilayah RW 08 dan RW 10 masih terdapat banyak lahan kosong yang tidak dimanfaatkan oleh warga dan dibiarkan begitu saja. Program yang akan dilaksanakan yaitu Penanaman Bibit Pohon yang bertujuan agar warga dapat membudidayakan pohon serta untuk memanfaatkan lahan kosong dan melestarikan lingkungan di Desa Karehkel. KKN dilaksanakan mulai tanggal 6 Agustus - 6 September 2019 dengan sasaran yaitu warga Kampung Bongas RT 1 \& 2/ RW 08 diantaranya Siswa/i di SMK Statika, SDN Karehkel 01, PAUD Faturahman, Majelis Al- Barokah, Majelis Nurul Iman, Ibu-Ibu Pengajian Kp. Bongas dan Kobong Al Hidayat.

dalam kaitannya dengan pengumpulan data penelitan yaitu wawancara terpimpin (guide interview) yang juga dikenal dengan sebutan wawancara berstruktur atau wawancara sistematis. Wawancara tidak terpimpin (un-guided interview) yang dikenal dengan istilah wawancara sederhana atau wawancara bebas. Peneliti juga melakukan observasi langsung kepada masyarakat sebagai suatu kegiatan membandingkan fakta dan budaya yang ada dilingkungan setempat. Observasi adalah cara menghimpun bahan-bahan keterangan yang dilakukan dengan mengadakan pengamatan dan pencatatan secara sistematis terhadap fenomena- 
fenomena yang diajdikan obyek penelitian. Peneliti melakukan pendekatan terhadap masyarakat di Desa Karehkel, dimulai dengan Pegawai Kantor Desa, Tokoh Masyarakat, Ibu-Ibu, Bapak-Bapak, Anak-

\section{REALISASI PROGRAM}

Program Penanaman Bibit Pohon ini dilaksanakan pada tanggal 1 September 2019 yang berlokasi di Desa Karehkel bersama Anggota DPRD Kabupaten Bogor, Sekretaris Desa Karehkel dan Warga. Kegiatan penanaman pohon ini disertakan dengan program senam bersama dan Pembagian 6000 Bibit Pohon. Tujuan dari pembagian bibit pohon ini agar warga dapat membudidayakan pohon, mengelola dan memanfaatkan lahannya yang kosong. Bibit yang diberikan adalah jenis bibit pohon albasia, trembesi, ketapang kencana, gmelina (jati putih), kelor, gaharu, meranti, jambu biji merah, dan manggis. Kami berharap melalui program ini masyarakat Desa Karehkel dapat memanfaatkan lahan yang ada disekitar rumah dan lahan yang kosong untuk melestarikan lingkungan di Desa Karehkel. Proses distribusi 6000 bibit pohon tersebut dengan cara mengumpulkan warga di lapangan dan selebihnya dibagikan kepada kelompok KKN UIKA di masing-masing Desa, agar bibit pohon bisa diperoleh oleh warga Kecamatan Leuwiliang dan sekitarnya.

\section{Program lain yang dilaksanakan}

\section{Workshop Penyuluhan Hukum "Pencegahan Narkotika Dan Seks Bebas"}

Kegiatan ini merupakan kegiatan pengabdian kepada masyarakat yang bertujuan untuk mencegah penyalahgunaan pemakaian narkoba dan perilaku seks bebas di kalangan Siswa/i yang dilaksanakan di SMK Statika Desa
Anak dan masyarakat Desa Karehkel. Peneliti juga melakukan sosialisasi dan penyuluhan kepada masyarakat sesuai program yang sudah direncanakan.

Karehkel. Tujuan dari kegiatan Workshop ini yaitu menjadi sasaran kepesertaan adalah remaja atau para pelajar, karena pada kelompok usia ini sangat rawan dan rentan melakukan penyalahgunaan narkoba yang disebabkan karena secara psikologis usia remaja berkencenderungan untuk mencoba hal yang baru dan ingin menunjukkan diri kepada pihak yang lainnya. Menurut data dari BNN penyalahgunaan narkoba dikalangan remaja mencapai $80 \%$ dan itu adalah angka yang tertinggi diantara usia lainnya. Hal itu menjadi bahan pertimbangan kami dalam melakukan workshop ini. Dengan mengundang saudara Aiptu Alan Sutiawan $\mathrm{S}, \mathrm{H}$ sebagai pemateri dan tanya jawab dengan Siswa pada acara kami selain itu acara ini juga dihadiri oeh Ketua Yayasan, Kepala sekolah dan Guru-Guru yang ada di SMK Statika, juga Panitia KKN Kelompok 11/12 dan seluruh peserta siswa/i SMK Statika. Alhamdulillah anakanak dipandu oleh Mahasiswa dan dapat mengikuti dengan baik. Dengan dibantu oleh seluruh team panitia KKN kelompok $11 / 12$. Kegiatan ini dapat terlaksana pada hari Kamis tanggal 25 Agustus 2019 Pukul 09.00 s/d 11.40 WIB. Dilaksanakan di SMK Statika Karehkel dengan seluruh Mahasiswa/i KKN Kelompok 11/12 turut membantu pelaksaan kegiatan tersebut. Jumlah Peserta yang mengikuti sekitar 60 siswa di SMK Statika.

\section{Kegiatan Mengajar di SMK Statika}

Kegiatan mengajar di SMK Statika di Desa Karehkel dilaksanakan selama tiga 
minggu, dimulai pada tanggal 12 Agustus hingga 31 Agustus 2019. Permasalahan yang dihadapi oleh SMK Statika adalah kurangnya tenaga pendidik, karena sekolah ini didirikan dan dimaksudkan bagi mereka yang kurang mampu, sehingga tenaga pengajar pun dibayar dengan bayaran yang seikhlasnya. Untuk itu, setiap hari semua mahasiswa KKN bergantian mengajar di SMK Statika. Di setiap minggu ada 6 (enam) mata pelajaran yang diajarkan yaitu Pendidikan Agama Islam, Bahasa Inggris, Matematika, PKN, Sejarah Indonesia, dan Komputer. Setiap mata pelajaran diajarkan di waktu dan hari yang berbeda yaitu dimulai dari hari Senin sampai Jumat. Ada beberapa kendala yang dialami selama melakukan kegiatan mengajar di SMK Statika. Kendala pertama, yang dialami selama melakukan kegiatan mengajar di SMK Statika adalah kurangnya sarana dan prasara di sekolah seperti ruang kelas yang hanya tersedia 4 (empat) ruangan dan tiap-tiap kelas yang tidak memiliki kursi serta meja bagi siswanya. Salah satu ruang kelas juga digabung dengan kantor guru. Kendala kedua, yaitu jumlah rombongan belajar yang melebihi aturan yang ditetapkan oleh Dinas Pendidikan, jumlah rombongan belajar di SMK Statika khususnya kelas X yaitu 50 (lima puluh) orang di setiap kelasnya. Dengan jumlah rombongan belajar dan yaitu kurangnya sarana dan prasarana yang mengakibatkan pembelajaran menjadi tidak kondusif dan efektif. Untuk mengatasi permasalahan rombongan belajar, kami menambah jumlah pengajar sehingga setiap pembelajaran dilakukan oleh dua sampai tiga orang agar dapat membuat suasana kondusif dan efektif.

\section{Kegiatan Bimbel Bahasa Inggris}

Bimbel Bahasa Inggris di Desa Karehkel dilaksanakan setiap hari Sabtu dan Minggu di Kobong Al Hidayah Mubtadiin. Kegiatan bimbel Bahasa Inggris ini bertujuan untuk memberikan tambahan kosak kata (vocabulary) pada anak-anak di Desa Karehkel, dengan memberikan pengetahuan mengenai pengucapan (spelling) yang baik dan benar, serta meningkatkan rasa percaya diri anak-anak di Desa Karehkel dalam menggunakan Bahasa Inggris. Kendala yang dihadapi selama kegiatan bimbel Bahasa Inggris ini adalah anak-anak sulit untuk menghafal kosa kata dikarenakan waktu yang terbatas sehingga kami memutuskan untuk memberikan materi berupa lagu.

\section{Kegiatan Mengajardi TPA}

Kegiatan mengajar di TPA Desa Karehkel dilaksanakan selama 3 (tiga) minggu, dimulai dari minggu pertama bulan Agustus 2019. Pengajaran dilaksanakan di 3 (tiga) tempat diantaranya di TPA Al Barokah (dimulai ba'da maghrib), Majelis Nurul Iman As Sa'adah (dimulai ba'da ashar), dan Kobong Al Hidayah Mubtadiin (ba'da maghrib). Antusias adik-adik dalam belajar mengaji sangat semangat sekali, sehingga kami yang mengajar lebih bersemangat lagi untuk bertemu dan belajar bersama dengan adik-adik di Desa Karehkel. Materi yang kami ajarkan kepada adik-adik yaitu seputar asmaul husna, tajwid, makhrojul huruf, nama- nama nabi, malaikat, rukun islam dan rukun iman, praktek solat dan 20 (dua puluh) sifat Allah SWT. Kami pun mengadakan kegiatan cerdas cermat di TPA untuk menambah semangat adik- adik untuk mengaji. Kami juga menggunakan metode audio- visual dalam menampilkan materi tentang kisah para Nabi. 
5. Kegiatan Seminar Edukasi Pasar Modal Syariah

Seminar Pasar Modal Syariah diselenggarakan pada hari Rabu, 21 Agustus 2019 Pukul 09.30 s/d 12.00 WIB bertempat di kantor Kecamatan Leuwiliang Kabupaten Bogor. Kegiatan ini bertujuan untuk memberikan wawasan dan pengetahuan kepada masyarakat tentang investasi di pasar modal syariah, menumbuhkan jiwa kompetitif melalui pengetahuan ekonomi, dapat menumbuhkan kesadaran akan pentingnya berinvestasi, dan membagikan pengetahuan mengenai investasi di pasar modal syariah. Perwakilan dari fakultas ekonomi menjadi panitia di acara Seminar Edukasi Pasar Modal Syariah, bekerjasama dengan BEI (Bursa Efek Indonesia), acara yang diselanggarakan berjalan lancar sesuai dengan rencana walaupun hasilnya kurang maksimal dan antusianisme dari masyarakat menanggapi acara tersebut sangat baik.

\section{Kegiatan Seminar Ekonomi Tentang Literasi Keuangan}

Seminar Ekonomi Tentang Literasi Keuangan diselenggakan pada hari Kamis, 25 Agustus 2019 Pukul 10.30 s/d selesai di SDN Karehkel 01. Tujuan dari kegiatan tersebut untuk mengenalkan keuangan sejak dini kepada Siswa/i di Sekolah Dasar. Tujuan dari kegiatan ini agar anakanak dapat mengenali jenis uang dengan baik dan menggunakan uang dengan baik dan teratur, agar tidak boros dalam menggunakan uang. Anak- anak sangat semangat dalam mengikuti kegiatan seminar ekonomi tentang literasi keuangan ini karena kami membuat presentasi seputar keuangan dengan semenarik mungkin.

\section{Membuat Celengan Dari Bahan Bekas}

Kegiatan membuat celengan dari bahan bekas dilaksanakan pada hari Sabtu, 24 Agustus 2019 Pukul 10.30 s/d selesai di SDN Karehkel 01 dengan tema "Rajin Pangkal Pandai Hemat Pangkal Kaya". Melalui kegiatan ini anak-anak diajarkan untuk kreatif dan inovatif dalam membuat sarana untuk menabung dengan memanfaatkan barang bekas atau barang yang bisa di daur ulang menjadi barang yang berguna. Adapun kegiatan ini bertujuan untuk meningkatkan minat menabung dan sikap berhemat sejak dini kepada anak-anak Sekolah Dasar agar lebih bijak lagi dalam menggunakan uang dan memanfaatkan barang yang tidak bernilai menjadi barang bernilai. Dengan ini kami berharap ilmu yang kami ajarkan dapat diterapkan oleh anak-anak dan menjadi suatu hal yang bermanfaat untuk kedepannya.

\section{Pelatihan Kewirausahaan Membuat Bola Susu}

Kegiatan Pelatihan Kewirausahaan dilaksanakan pada hari Jumat, 26 Agustus 2019 Pukul 09.00 s/d selesai di Majelis AlBarokah. Kegiatan ini bertujuan untuk meningkatkan jiwa kewirausahaan kepada Ibu- Ibu di majelis dengan mengajarkan modal yang kecil (minimum) guna mendapatkan hasil yang besar (maksimal). Dalam kegiatan ini kami memberikan referensi pelatihan membuat bola susu agar dapat dipraktekan oleh ibu-ibu dikemudian hari dan dapat dijadikan sebuah ide usaha kecil di rumah.

\section{Sosialisasi Perilaku Hidup Bersih dan Sehat (PHBS)}

Mahasiswa Kuliah Kerja Nyata (KKN) dari fakultas ilmu kesehatan juga mensosialisasikan Perilaku Hidup Bersih dan Sehat (PHBS) di SDN 01 Desa Karehkel, Leuwiliang, Kabupaten Bogor, pada tanggal 22 Agustus 2019. Kegiatan 
ini dilakukan secara bergilir, memasuki kelas- kelas yang telah ditentukan oleh pihak sekolah. PHBS di Sekolah adalah sekumpulan perilaku yang dipraktikkan oleh peserta didik, guru dan masyarakat lingkungan sekolah atas dasar kesadaran sebagai hasil pembelajaran. Sehingga, secara mandiri mampu mencegah penyakit, meningkatkan kesehatannya, serta berperan aktif dalam mewujudkan lingkungan yang sehat.

\section{Pengajian Bapak-Bapak Dan Ibu- Ibu Di Kp. Bongas RW 08}

Program Pengajian di Kp. Bongas Bapak-Bapak dan Ibu- Ibu dilaksanakan setiap 1 (satu) minggu sekali dimulai dari tanggal 8 Agustus sampai 2 September 2019. Untuk Bapak- Bapak rutinan pengajiannya dilaksanakan setiap hari Kamis pukul 19.00-21.00 WIB. Sedangkan untuk Ibu-Ibu dilaksanakan setiap hari Jum'at pukul 07.00-10.00 WIB. Pengajian Bapak-Bapak dilaksanakan di Musholla dekat rumah Pak RW 08. Sedangkan Ibu-Ibu melaksanakan pengajian di Majelis Al Barokah. Sesekali Ibu-Ibu di RW 08 mengadakan pengajian dirumahnya dan mengundang mahasiswi KKN untuk hadir mengikuti kegiatan tersebut. Dengan sasaran Bapak- Bapak dan Ibu-Ibu, tujuan dari program kerja ini adalah mendekatkan diri dengan masyarakat sekitar agar mudah berinteraksi dan menjaga silahtuhrahmi dengan Ibu-Ibu ataupun dengan Bapak-Bapak di Desa Karehkel.

\section{Membantu Kader Posyandu}

Program selanjutnya yaitu membantu kader posyandu melaksanakan kegiatan rutin perbulan yang dilaksanakan pada tanggal 26 Agustus yang dilaksanakan di Majelis RW 08 RT 02 yaitu Majelis Nurul Iman, kegiatan yang dilaksanakan yaitu kesehatan Ibu dan
Anak, keluarga berencana, imunisasi dan peningkatan gizi, dan juga kesehatan untuk Ibu hamil.

\section{Pembagian Iqro, Juz'amma, \& Al- Qur'an di Bulan Muharram}

Pada tanggal 30-31 Agustus 2019 Kelompok KKN 11 dan 12 di Desa Karehkel Kecamatan Leuwiliang telah mengadakan program untuk memperingati 1 (satu) Muharram dengan pembagian AlQur'an, Juz Amma, dan Iqro yang di bagikan ke beberapa masjid, masyarakat, dan pengajiian TPA yang terdapat di Desa Karehkel. Program pembagian Al-Qur'an ini berjalan lancar dan tidak ada kendala apapun. Kami merasa senang ketika melihat kebahagiaan masyarakat Desa Karehkel ketika mendapatkan Al- Qur'an dan perasaan adik-adik yang begitu senang mendapatkan Juz Amma dan Iqro baru, karena hal ini memotivasi dan menambah semangat mereka untuk terus mengaji. Banyaknya sumbangan Al-Qur'an dari beberapa donatur ini sangat membantu kelompok KKN kami dalam agenda program pembagian Al-Qur'an ini. Kami mengadakan program ini karena melihat sebagian di pengajian TPA beberapa adikadik yang mempunyai Al-Qur'an, Juz Amma dan Iqro nya yang sudah rusak tetapi masih di pakai untuk mengaji, hal ini menyadarkan kami bahwa semangat mereka dalam belajar ilmu Agama sangatlah tinggi. Kami berharap dengan adanya pembagian Al- Qur'an ini membuat mereka bertambah semangat dalam mengaji dan membaca AlQur'annya.

\section{Pemeriksaan Kesehatan Dengan Cek Tekanan Darah}

Pada tanggal 15 Agustus 2019, mahasiswa KKN kelompok 11 dan 12 melaksanakan kegiatan cek kesehatan mengetahui tanda-tanda vital seperti tensi 
gratis kepada masyarakat RW 08. Agar masyarakat mengetahui tekanan darahnya saat ini guna mencegah terjadi penyakit yang ditimbulkan akibat tekanan darah tinggi dan tekanan darah rendah, dikarenakan banyak warga sekitar yang jarang mengecek kesehatannya dan masih mengabaikan hal tersebut. Hal ini tentu saja berbahaya, karena hipertensi yang tidak ditangani berisiko menyebabkan penyakit jantung, stroke, gagal ginjal, dan gangguan kesehatan lain yang bisa mematikan.

\section{Pemasangan Penampungan Air}

\section{Untuk Kobong Al Hidayah Mubtadiin}

Pemasangan penampungan air (toren) di Kobong Al Hidayah Mubtadiin dilaksanakan pada tanggal 25 Agustus 2019. Pemasangan toren dilakukan oleh para Mahasiswa dan dibantu oleh beberapa warga dan santri disana. Program pemasangan toren ini bertujuan untuk membantu Kobong Al Hidayah Mubtadiin yang sedang dalam tahap pembangunan dan untuk persediaan air jika sedang dalam musim kemarau.

\section{Sistem Pakar Identifikasi Penyakit Pada Pohon Pisang}

Program selanjutnya adalah mengidentifikasi penyakit pada tanaman pisang yang dilakukan oleh Ibu Freza Riana, S.Si., M.Si., dengan menggunakan aplikasi web yang ia buat. Program ini diarahkan untuk warga yang berprofesi sebagai petani pisang agar dapat mengetahui penyakit pada tanaman pisang dan bagaimana cara merawatnya dengan baik.

\section{Bimbel Komputer}

Kegiatan ini merupakan kegiatan pengabdian kepada masyarakat melalui Anak-Anak kecil yang duduk di bangku SD sederajat. Yang bertujuan untuk menyampaikan segala ilmu yang kami dapatkan dari bangku Sekolah Dasar hingga bangku kuliah dan lebih tepatnya memahami ilmu-ilmu yang sedikit banyaknya menyangkut tentang komputer. Kegiatan belajar mengajar ini dilaksanakan pada hari Sabtu dan Minggu pada pukul 12.30-14.10 di Pesantren/Kobong Desa Karehkel. Kami dibantu dengan temanteman Mahasiswa/i lainnya dalam melaksakan tugas kami belajar mengajar selama 1 (satu) minggu 2 (dua) kali. Tidak ada kendala yang kami keluhkan kecuali hanya hal-hal yang merupakan kondisi yang dimaklumi karena Pesantren/ Kobongnya yang masih baru. Dan fasilitas yang seadanya sehinga siswa kurang berkonsentrasi karena keadaan kelas yang panas dan tanpa meja dan kursi. Selebihnya kegiatan belajar mengajar berjalan lancar dan siswa/i dapat menerima dan mengikuti dengan baik.

\section{Kegiatan Mengajar di Paud Faturrahman}

Kegiatan mengajar di Paud Faturrahman Desa Karehkel dilaksanakan selama 3 (tiga) minggu, dimulai pada tanggal 13 Agustus hingga 30 Agustus 2019 kegiatan mengajar dilaksanakan 1 (satu) minggu 2 (dua) kali pertemuan, yaitu pada hari Selasa dan Jum'at. Kegiatan yang dilaksanakan di Paud Faturahman memiliki dua rombongan belajar. Rombongan belajar pertama dimulai dari jam 7:30 sampai jam 9:30 sedangkan rombongan belajar ke dua di mulai dari jam 10:00 sampai 12:00. Kegiatan pembelajaran pada hari Selasa di Paud Faturrahman yaitu dimulai dengan baris dihalaman dan berolahraga, dilanjutkan masuk ke dalam kelas dan belajar mengenal huruf lalu istirahat dan pulang. Sedangkan kegiatan yang dilaksanakan pada hari Jum'at di Paud 
Faturrahman yaitu dimulai baris dihalaman, lalu berwudhu setelah itu masuk kedalam kelas untuk melaksanakan kegiatan sholat dhuha bersama dilanjutkan membaca surat-surat pendek dalam AlQur'an dan membaca hadits-hadits, dilanjutkan dengan istirahat lalu pulang.

\section{Penyuluhan Hukum Perkawinan Dan Perceraian}

Kegiatan ini merupakan bentuk pengabdian kepada masyarakat baik oleh dosen maupun mahasiswanya. Acara ini dilaksanakan di Majelis Nurul Iman Desa Karehkel Kecamatan Leuwiliang pada hari Senin tanggal 26 Agustus 2019. Kegiatan ini bertujuan agar Ibu- Ibu yang ada di majelis tersebut mengetahui mengenai jalur penyelesaian hukum keseluruhan mengenai perkawinan dan perceraian. Harapan kita setelah ini agar segala permasalahan hukum mengenai perkawinan dan perceraian bisa terselesaikan dengan jalur hukum yang tepat, sehingga tidak terjadi suatu permasalahan yang ditimbulkan dikemudian hari. Acara ini diisi oleh Pak Sutisna dan Mahasiswa sebagai penyedia tempat dan sosialisasi ke warga mengenai acara. Acara ini diikuti kurang lebihnya 40 peserta diantaranya yaitu Ibu-Ibu Majelis Nurul Iman dan Mahasiswa/i KKN 11/12 Desa Karehkel UIKA Bogor. Dengan Pemateri yaitu Bapak Dr. Sutisna, N.A. Beliau sebagai Dosen Pembimbing Lapangan KKN kelompok 11/12 Desa K arehkel sekaligus Dosen Hukum Islam di Fakultas Agama Islam.

\section{Bimbel Anak-Anak Di Posko Perempuan}

Bimbel atau bimbingan belajar merupakan kegiatan pembelajaran tambahan yang diberikan kepada anakanak di kampung Bongas RW 08. Pada kegiatan bimbel yang di adakan di
Posko perempuan (posko 12) di khususkan bimbingan belajar pada anakanak kisaran Sekolah dasar. Kegiatan bimbel ini bertujuan untuk menambah intensitas belajar anak-anak yang bertempat tinggal dengan posko perempuan. Sistem bimbel yang diadakan cukup fleksibel, anak- anak boleh mendatangi posko kapanpun mereka mau, hanya saja di batasi paling malam pukul 20.00 WIB. Adapun mata pelajaran yang pernah di ajarkan yakni Matematika, IPA, IPS, dan Bahasa Inggris.

\section{Lomba Menggambar dan Mewarnai}

Kegiatan ini dilaksanakan pada tanggal 18 Agustus 2019 di Posko lakilaki. Kegiatan ini dilakukan untuk memberikan nilai positif guna melatih kreatifitas anak-anak, melatih daya fikir anak-anak, agar kelak dapat lebih meningkatkan kreatifas. Tujuan dari kegiatan ini adalah mendekatkan diri dengan anak-anak dan warga di Kampung Bongas RW 08 kelompok 11 dan $12 \mathrm{KKN}$ UIKA agar mudah berinteraksi dan menjaga silaturahmi di lingkungan masyarakat RW 08.

\section{Pembagian Buku Calistung Dan Bacaan Pintar}

Pada tanggal 03 September 2019 kelompok KKN 11 dan 12 mengadakan program pembagian beberapa buku bacaan dan calistung. Pembagian tersebut ditujukan untuk murid-murid di PAUD Faturrahman. Kegiatan ini disambut baik oleh pihak dewan guru di PAUD Faturrahman juga wali murid yang hadir menyaksikan secara langsung. Begitupun murid-muridnya sangat antusias ketika kami membagikan dihadapan mereka. Program ini bertujuan agar anak- anak di PAUD memiliki referensi acaan yang beragam, juga menumbuhkan sikap gemar membaca pada tiap individu. Kita ketahui 
bahwa dengan membaca maka kita akan mengetahui luasnya dunia dengan berbagai ragam budaya. Berharap setelah hadirnya buku-buku tersebut anak-anak lebih termotivasi lagi dalam hal belajar maupun membaca. Semoga dengan pembagian beberapa buku ini kami dapat berpartisipasi dalam mencerdaskan anak bangsa.

\section{Senam Bersama}

Program selanjutnya yaitu, senam pagi yang dilaksanakan di Lapangan Pandu, Desa Karehkel pada tanggal 1 September 2019. Dalam acara Penanaman Bibit 6000 pohon bersama masyarakat setempat. Mahasiswa berharap dengan mengadakannya senam pagi pertama kali di Desa Karehkel membuat masyarakat agar antusias mengadakan kegiatan senam secara rutin setiap minggunya, karena senam pagi mempunyai manfaat menurunkan berat badan, membangun otot, mengontrol diabetes, mengontrol tekanan darah, meningkatkan kualitas tidur, menyehatkan jantung, dan mendukung kesehatan mental.

\section{Cerdas Cermat}

Kegiatan cerdas cermat ini adalah suatu wahana untuk menambah wawasan dan meningkatkan pengetahuan. Kegiatan cerdas cermat ini dilaksanakan pada tanggal 26 Agustus 2019 yang bertempat di salah satu TPA di Kampung Bongas Desa Karehkel. Antusias adik-adik yang mengaji begitu semangat dalam mengikuti kegiatan cerdas cermat ini. Antusias mereka dalam menjawab setiap pertanyaan yang di ajukan dan kegembiraan mereka setiap mendapat point

\section{KESIMPULAN}

Pelaksanaan Kuliah Kerja Nyata (KKN) Tematik Terintegrasi Universitas Ibn Khaldun Bogor tahun 2019 di Desa nilai. Harapan kami mengadakan kegiatan cerdas cermat ini untuk memberikan wawasan dan meningkatkan pengetahuan adik- adik mengenai materi yang sudah kami ajarkan kepada mereka. Jumlah peserta didik yang mengaji ada 20 (dua puluh) orang, dan kami membagi menjadi 4 (empat) kelompok. Pertanyaan yang kami ajukan seputar tentang pengetahuan ilmu Agama, seperti rukun islam, rukum iman, nama-nama Nabi dan Malaikat, serta asmaul husna. Kegiatan ini memberikan semangat kepada adik-adik untuk terus belajar mengaji.

\section{Pelaksanaan Lomba 17 Agustus}

Peringatan 17 Agustus adalah momen dimana setiap lapisan masyarakat Indonesia dapat merasakan perjuangan para pahlawan dalam rangka memerdekakan negeri ini. Salah satu manfaat adanya kegiatan 17an ialah untuk meningkatkan kebersamaan dan persatuan. Karena itu kegiatan ini diadakan guna mempererat silahturahim antar sesama warga khususnya di Kampung Bongas, Desa Karahkel. Selain itu kegiatan ini diadakan untuk menumbuhkan dan meningkatkan jiwa patriotisme masyarakat. Perlombaan yang diadakan pun bervariasi, mulai dari lomba kelereng, lomba balap karung, lomba makan kerupuk, lomba joget balon, lomba galah barang, lomba sepak bola Ibu-Ibu. Karena kegiatan ini pertama kalinya diadakan di Kampung Bongas RW 08, masyarakat dari kalangan Anak-Anak hingga Ibu- Ibu sangat antusias mengikuti perlombaan dari awal kegiatan hingga akhir.

Karehkel Kecamatan Leuwiliang Kabupaten Bogor selama 30 (tiga puluh) hari berjalan dengan lancar. Program 
utama yang dilaksanakan yaitu penanaman dan pembagian 6000 bibit pohon. Selain program penanaman pohon masih ada program lainnya yang dilaksanakan. Dalam setiap pelaksanaan program kerja dapat dikatakan berjalan dengan baik. Antusias dari masyarakat yang cukup tinggi, dimana masyarakat turut aktif dalam program kami sehingga masyarakat dapat mengambil manfaatnya. Meskipun program KKN UIKA berjalan dengan baik, masih ada kendala dan hambatan yang terjadi saat pelaksanaan program, seperti sulitnya mengumpulkan masyarakat saat awal mulai KKN dan kurangnya persiapan saat melaksanakan programnya.

\section{SARAN}

Saran yang ingin kami sampaikan pada laporan Kuliah Kerja Nyata Tematik Terintegrasi ini adalah untuk Desa Karehkel agar masyarakat mengerti bahwa program KKN ini bukan hanya untuk kepentingan mahasiswa saja tetapi juga

\section{DAFTAR PUSTAKA}

Arief A Zainal. (2016). Metodologi Penelitian. Bogor : UIKA PRESS

Data Administrasi Profil Desa Karehkel

Prasetya, E. (2018). Pemberdayaan Masyarakat Tentang Kesehatan,
Dampak bagi lingkungan dan masyarakat banyak sekali, dimulai dari penanaman dan pembagian bibit pohon yang salah satu tujuannya untuk melestarikan lingkungan di Desa. Lalu dari pendidikan membuat warga memotivasi anak-anaknya untuk semangat belajar serta dapat menghemat pemakaian uang serta pemanfaatan barang bekas menjadi barang yang berguna. Dari segi kesehatan warga sangat antusias saat cek kesehatan tekanan darah karena agar warga dapat mencegah penyakit yang ditimbulkan oleh tekanan darah. Lalu dari segi hukumnya yaitu memberikan penyuluhan kepada siswa SMK agar tidak menyalahgunakan narkoba dan perilaku seks bebas.

untuk kepentingan masyarakat setempat, dimana mahasiswa hanya menjadi fasilitator dan motivator yang membantu memecahkan masalah, sehingga diharapkan partisipasi Desa dalam program KKN dapat lebih baik lagi kedepannya.

Pendidikan dan Kreatifitas. Abdi Dosen: Jurnal Pengabdian Pada Masyarakat 2 (1), 19-25.

https://www.lead.co.id/tanam-6000- bibitpohon-kelompok-11-12-kkn-uikadiapresiasi-wargal 